\title{
煙草の放射線照射
}

\author{
大阪府立放中研 砂田 毅, 加藤智雄, 木下商策
}

\section{Irradiation on Tobacco}

Tsuyoshi Sunada, Norio Kato and Shosaku Kinoshita

Division of Sanitary Engineering, Radiation Center of 0saka Prefecture

For determining the feasibility of using irradiation in the preparation of tobacco, a preliminary study on irradiation of tobacco was attempted at our laboratory. The results obtained are as follows:

1) Tobacco leaves in the drying process acquired good aroma of fermented or aged tobacco by irradiation at a dose of $1 \times 10^{6}$ rads of Co-60 $\gamma$-rays, whereas control unirradiated leaves had green-note smell of green leaves.

2) Tobacco flea beetles and tobacco moths and their larvae were killed in a dose less than $1.7 \times 10^{5}$ rads of $\gamma$-rays.

3) "Peace" (one of the representative brand of cigarette in Japan) irradiated in a dose of $1 \times 10^{6}$ rads of $\gamma$-rays was prefered after 3-4 weeks to unirradiated cigarette; many of panel members appealed that irradiated cigarette became milder than the control.

4) Bacterial plate count on the irradiated cigarette after one month storage in a show window case was only a few per piece, whereas that of the control of unirradiated cigarette was of the order of $2 \times 10^{4}$ per piece.

5) Reduction in concentration of nicotine in aqueous solution was observed by exposure of various doses of $\gamma$-irradiation, but nicotine content of irradiated cigarette was not significantly different from the control unirradiated cigarette. For the explanation of the difference between the results in vitro and in vivo, tobacco leaf was stained with Dragendorfs reagent and many red spots (nicotine) were found to localize which led to the assumption that nicotine in a leaf might be contained not diffusely but concentratedly. 
No significant difference in nicotine contents of main stream of cigarette smoke between the cigarette irradiated in a dose of $1 \times 10^{6} \mathrm{rads}$ and unirradiated cigarette was observed.

6) There was no significant difference in crude tar content from cigarette smoke between the cigarette irradiated in a dose of $1 \times 10^{6} \mathrm{rads}$ and unirradiated cigarette.

7) No significant difference was observed in maximum temperature of smoking between the irradiated and unirradiated cigarette.

8) Toxicity test of the water in which the main stream smoke of the irradiated cigarette was dissolved by using Japanese gold fishes did not show the difference from the unirradiated.

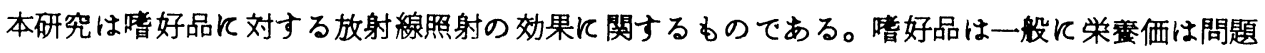
にならず，その風味を賞がんするものであるから狭義の食品に比べて，照射奻果の検即の範囲は よク少なくて昘むが，他方いるんな問題点が生してくる。その意味から「喍好品に対する放射線 照射奻果」を観祭することは興味ある研究対象であろう。一般に高線量の照射を受けると跓好品 （食品）は焦げ臭味を呈するょろになることが多いから，逆に「焦げた句い中味を主体とするも のには照射は適しているのではないか」とも考光られる。照射食品として（米国で）許可された ベーコンが他の食品に比し500万 radのことき高線量の照射を受けているに拘らずその風味

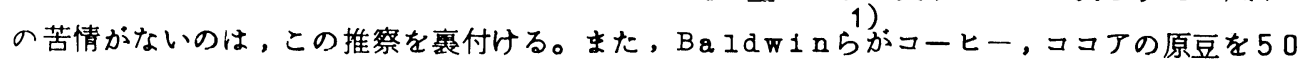
〜900万 rad照射することにより（抽出速度と抽出率が促進されると共に）その風味が高品 媇化されることを報告しているのもこの例として良いだろう。著者らす，紅茶，コーヒー，ココ ア，緑茶を 1 万〜100万 rad照射してみたか，高線量では勿いは枯草様となり，味は苦くな ク，到底领用に耐光ないものになったことを経験した。しかしこのよろな結果は，原材料を照射 しないで最終製品を炤射したためと考兄られ，原材料を照射した場合にはまた異なった結果が得 られるものと考えられる。

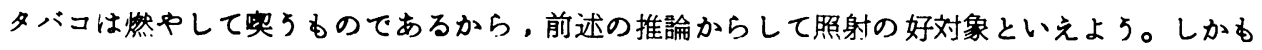
タバコはニコチンのごときアルカロイドを含有するのみならず，発癌物質を燃焼によって生成し，

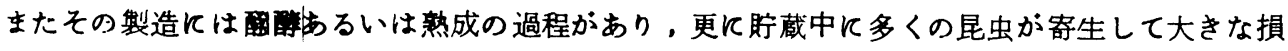
害を与えるので，照射がこれらにどのよろな効果を与兄るかを観察することは誠に興味梁い。し かしながらそれには多大の時間と人手を必要とするので，以下に大雑把に観察した予報を記す。 照射には尃らC○ー60線源を使用した。

\section{I 乾燥莱住対す万照射}

収獲された葉タバコは続いて䫒燥飞附される。この乾燥葉を１００万 rad（線量率５０万rad

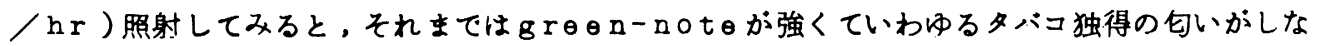


いものが，照射によって魏郁たるタバコ特有の芳香を放つようになった。この事実はタバコ製造 の過程で最す重要な酸醉熟成処理に放射線照射が有用である可能性を示晙している。かが国では タバコは専売品であるため，原料葉の入手がわれわれには困難なので，これ以上のことはできな かったが，関係当局の試行を促しておきたい。

\section{I寄生昆虫火対する照射}

タバコは载培中から最終製品に至るまで多種類の昆虫によって侵される。そのための年間損害 類は莫大なすので，各国の悩みの種となっている。そればかりでなく，成虫，あるいはその幼虫， 卵が附着している市販タバコが消費者を憤慨させ，製造者を恐縮させている。消費者からしばし ば苦情の出るのはタバコシバンムシやチヤマダラメイカあるいはその幼虫, 卵の寄生である。こ れらは製品に寄生して孔を穿ち通気抵抗を変え，また味を苦くして不快さを与える。タバコシバ ンムシの標本がッタンカーメンの墓の壼の中で発見されていることからして，この昆虫は少くと る 3,500 年前にエジプトに存在していたことは皦いがない。これらの昆虫のコントロール法と して現在行なわれているのはエチレンオキサイド, 青酸, メチルブロマイド等のガス鈤蒸法,ビ レトリン油等の噴霧法等があるが，それにす拘らず市販品にこれらの昆虫が生きたま〉附着して いることは，現在の昆虫コントロール法が不満足であることを示しているようである。

タバコ倉庫にむらがるこれら昆虫を入手してきて，タバコをときはししたすのと共に，50万 および17万rad照射してみたが，いずれる照射後即死していることがみられた。入手した昆虫 が左程多くなかったので，C0ー60 r線によるLDー50量が測定できなかったが，少なくとも 17 万radより低い線量でコントロールできる見込みはある。（楾量率５０万 rad／hr）。

\section{III 香 然味}

以下に述へる観察はすへて最終品について行なった。その理由は前述の通りである。

「ピース」および「ひかり」を5万，50万，100万rad照射（線量率50万rad/hr) したすのは，照射直後はいわゆる照射臭と共飞枯草莫が強く，明らかに照射されないものに比へ て悪化していることが認められた。しかし3〜4週間放置した後これらを研究所の所員をバネ ルとして盲試験による香契味テストを行なってみたところ，50万および 100 万 rad照射され たタバコの方が，より好ましいという回答を得た。より好ましいという回答者にその理由を举げ て黄ったところ，上り刺战的でない，マイルドであるといろ意見が多かった。㖺好品の風株は高 粐と考えられるすのはどマイルドなるのである傾向が強いが，下手をすると呆けた風沬になる。 パネル各個にす好みがあり，このテストそのものはまた大いに検討を今後必要とするが，バネル

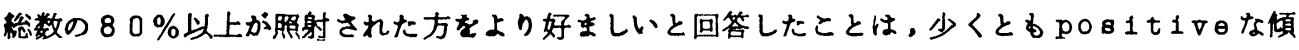
向を暗示しているとみなして良いだろろ。5万 rad 照射し 4 週後のすのでは対照との差は認め られなかった。

IV 両切タバコの品質

次に照射されたタバコの主な含有成分の変化を調べる必要があるが，そのためにはタバコ1本 の重量や密度が一定していないと困る。ところがテストを始めてみるとわが国の両切タバコがあ まりにこの条件に適合しないものが多いため困難を感した。 
密度のバラッキはラシオオラフィを行なって図示できるが，これは省略して，ここには1本当 クの重量のバラッキを示す。市販の「ビース」と「ポールモール」それそれ100本の1本当り の重量の頻度図を第 1 図に示す。

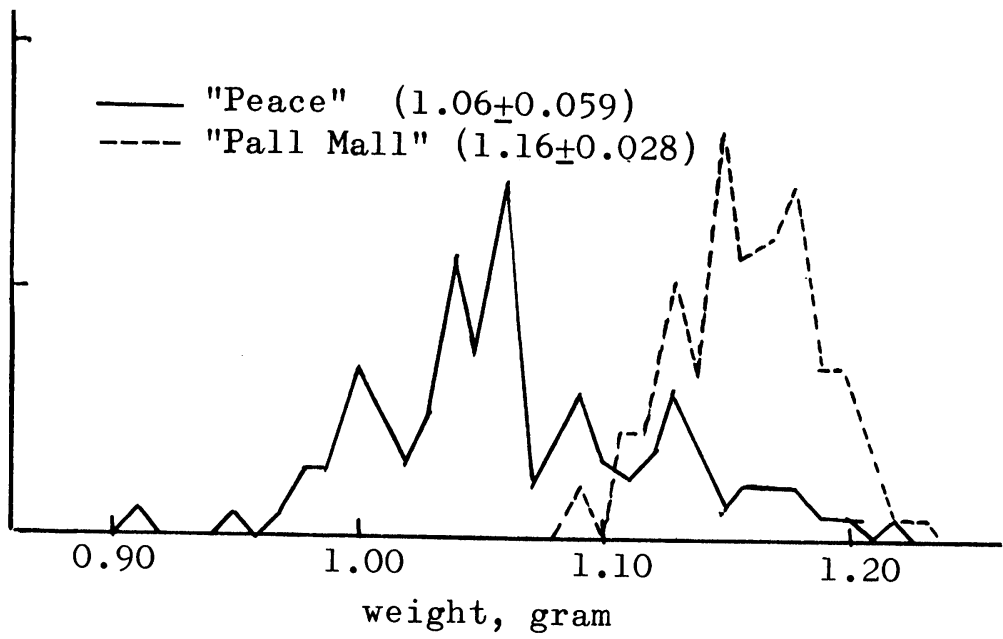

Fig. 1 Distribution of cigarette weight (100 cigarettes)

「ピース」の重量のバラッキの多いことが一目瞭然としているが，重い方ではキングサイズの 「ボールモール」の最大重量にまで渉っており，長さと太さはこれほどのバラッキはないので， この「ピース」は吸引抵抗が大きいので消費者は強く契わねばならぬのでイライラして怒るわけ である。更に然焼させてみる上，「ピース」は「ボールモール」に比へて裁断片の大きさが不均 一であるため然焼状態が大きく変化し，時には消えるるのさ光ある。この意味では明らかに「ピ 一ス」は「ボールモール」に比へて粗悪であり，品質管理に相当な技術的工夫と努力を必要々す るように思われる。

$V$ ニコチン量の照射による変動

タバコに含有されるアルカロイドの最も主なすのはニコチンであるがこれが照射によってそ の量がどのように変動するかを観察してみた。

各種浱度のニコチン水溶液をいろんな線量で照射してみた結果を第 2 図に示す。ニコチンの定 量はシアンプロマイドータナフチルアミン法によった。この定量法では照射によって変質した物 啠が同様な呈色を示しているかも知れないので，照射物のベーバークロマトクラフィを行なって

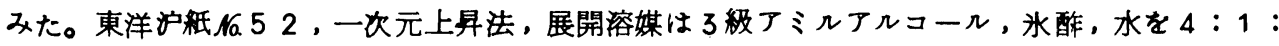
5 の制合に混じたるのを使用。ニコチンのR+以外の点にこの試薬による顕色物質が現われない ことから，照射によってニコチンから変化した物質はこの呈色反応にかかっていなとと推定した。 照射によってニコチンはその港度を減ずることがみられた。

次に，100万 rad照射した両切タバコ（「ピース」および「ひかり」）を5本宛一組とし てAＡＣのシリコタンクステン酸法によクニコチンの定量を行なってみた。その結果は，昭射 されないもの上含有ニコチン量に有意の差が認められなかった。 


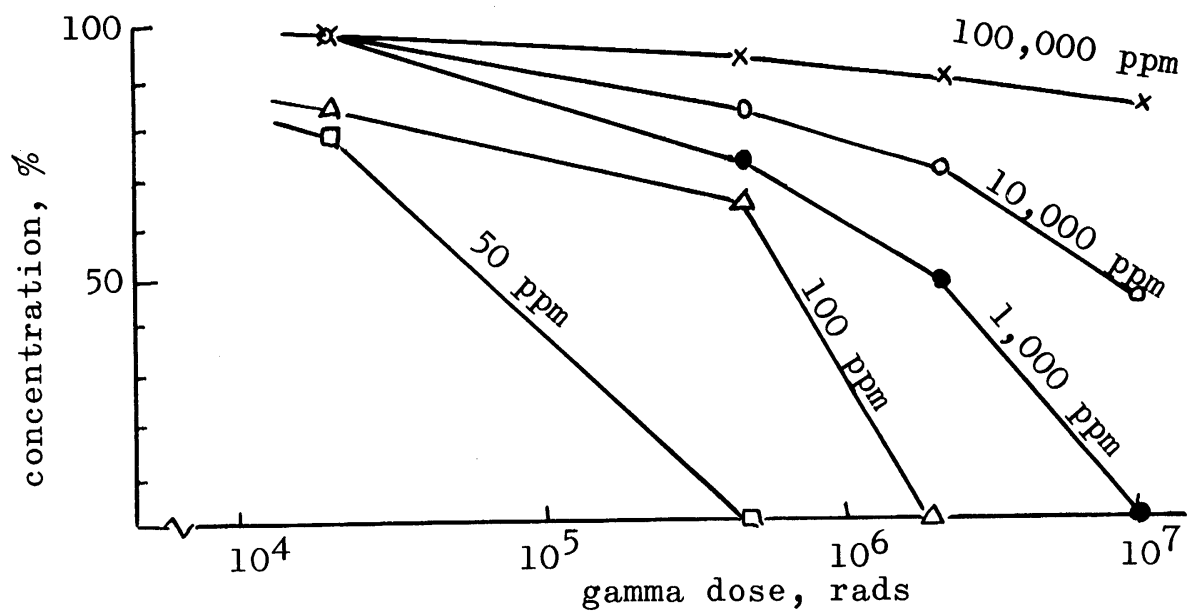

Fig. 2 Reduction of Nicotine concentration by gamma irradiation

1n V1tro ではニコチン量に変化が認められるに拘らず1n V1V0 では変化が認められ ない事実の解釈上してはいろいろ考光られるが，因みに，タバコ葉を中性洗剤で洗ってこれをド ラーゲンドルフ試薬で染色してみたところ，苯に陽性物質（赤色）がd1ffu日eに散在するの ではなくてュ゚caIに局在するのが認められた。（カラー写真は印刷の都合で省略）ドラーゲン ドフ陽性物質はニコチン等のアルカロイドのみでなくた々えばトリメチルアミン等も陽性であ るが，タバコを石油エーテル抽出，あるいはアセトン水で抽出した液をべーパークロマトクラフ 芒したところ。ほ上んど王倒的にニコチンが陽性物質の代表々みなされるこ.とからして，染色さ れたタバコ葉の赤色斑点はニコチンとみなしても良い上考えた。このよ ことがイn $\nabla 1 \nabla 0$ の照射では見掛上の濃度減少が見られぬことの一因と考えられる。

実際には，タバコは然やして典うのであるから，燃焼タバコからのニコチン量に差があるかど ろかを観察してみた。主煙中のニコチンの捕集は，5\%塩酸で湿らした綿球々それに続く0.5\% 塩酸水を入れたfrtted gIass fIIterを有するbubblerkよった。吸引速度は $1 \ell$ /分上した。捕集後，綿球上硝子継手を塩酸水て洗い，これ上bubbI日r中の捕集液上を合 せて前述の顕色法によりニコチンを定量した。タバコの燃焼は一本の全長を燃やさないで3／4 長で止めた。その結果，100万 rad照射した「ピース」，「ひかり」，「ボールモール」いず れも照射しないものとその主煙中のニコチン量に有意の差を認めなかった。

\section{पタール量}

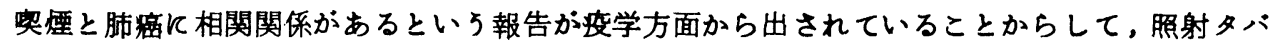
コからの発䊩物兵が対照に比へて差があるかとうかを観察して扔かねばならぬ。しかしながらタ バコが然焼することによってpyro1y日1日を起して発癌物質を形成する場合，性々んどそれは タール中に含まれることが示されているから，然焼タバコの主煙中の粗タール量を測ってみた。 アセトンを入れた捕集瓶を 4 本直列にし，3本までをドライアイス・アセトン冷媒で冷却して粗 タールが捕集された。捕策後アセトンで硝子継手および捕策瓶を洗って,ナセトンを蒸発させて 
乾燥し，後テジータ中に入れて重量法により測定し然焼は前述の通り前 $3 / 4$ 長までにした。 吸引速度は $1 \ell /$ 分。その結果，100万 rad照射された両切タバニ（「ピース」，「ボールモ 一ル」)は，照射されない煙草とその主煙中の粗タール量に有意の差はなかった。一般に発癌物 質のほ上んどは中性タール分疦のそれす四塩化炭素抽出分周に含主れることが報告されているが。

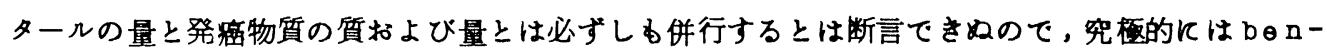

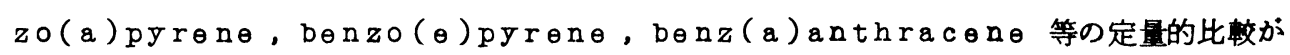
必要である。

VII 燃焼温度

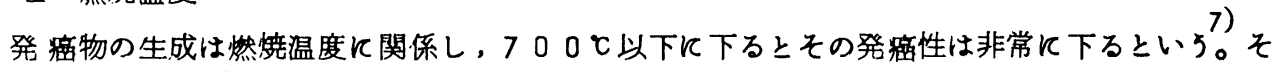

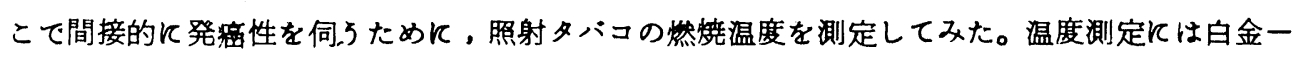
白金ロシウム熱電対 (径 5/100 m ) を両切タバコの断面中央部に㨂入設置して，然焼中の温度 変化を記録してみた。吸引速度 $1 \ell /$ 分て連続吸引の場合，10万万 rad照射の「ピース」で

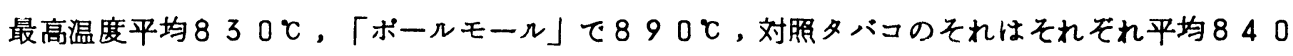
C，880てであり，照射タバコ々対照では然焼最高盜度に有意の差は認められなかった。被検 者がad l1b1tum K桇った場合の燃焼最高温度は100万rad照射の「ピース」て平均 $828 \mathrm{C}$ ，「ボールモール」で833C，対照タバコのそれはそれぞれ平均833C，833C であった。この場合です照射タバコと対照とに有意の差は認められなかった。

\section{䜣 附着細菌}

タバコの附着一般細菌数が照射によってとのように変化するかを観察してみた。そのため，市 販「ピース」を無菌的に紙を除いてその細断片を無菌水に入れ，よく摲拌して，この一部を普通 寒天培地に混合培してみた。その結果による上， 1 本当り平均 2 万個の細菌数の存在を認めた。 菌の大多数はbac111usの属上moIdK属するすのであった。他方１００万ｒad照射した 「ピース」を照射直後同様な操作で細菌数を測定してみると，1 本当り平均数十個の存在を認め た。100万 rad照射された「ピース」をタバコ小売店にみられるショーウインドーケースに 照射されていないるの上共に収めて1 カ月後にその附着細菌数を測定してみる上，照射タバコで はは々んど菌の存在を認め得なかった。他方照射されていない対照のタバコでは相変らず 2 万個 のオーダーの一般細菌数を認めた。すなわち，照射タバコは細菌もコントロールされている。

\section{X 毒性試験}

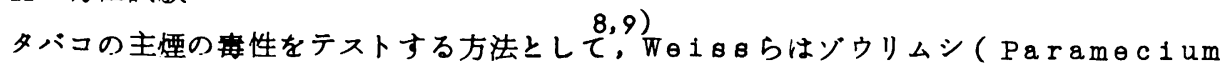
a ureI1a）を使用し，捕集水中で90分以内の平均生存時間を以て比較し，有成分はその gas phase Kあるこ上，通常のフィルターつきタバコはその毒性を除く効果がは上んどない

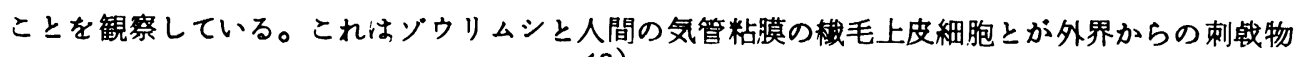
に対する生理的反応が類似していることから生物試験にこの虫を適用したすのである。私共は， 彼等が使ったゾウリムシが主煙中のニコチンやフェノールに対する90 分致死灌度が 1,000 ppm 以上であるのに不便を感じたので,これらの致死涨度が 24 時間で数 $10 \mathrm{ppm}$ である和金( 金 魚)を使用して每性試験を行なってみた。毒性試験を行ならのは，照射タバコが照射されないる 
のに比へ毒性が增強してはいないかを検討しておく必要があるからである。

主煙を $0.5 \%$ 塩酸水て捕集し，この液中のニコチン量を定量して，これと同浱度のニコチンの みを含む対照液を作ク，この2者を試料として，和金の 24 時間 T Lm 值を両者について比較した。 捕集液は塩酸を中和して対照液々同じ $\mathrm{pH}$ 值についてテストが行なわれた。その結果は両者に有意 の差を認めなかった。

このテストでは主煙中の有機溶性の毒性物質については久けているので，更にこれらについて あテストが行われなければならない。

おわりに

以上に述ベたことき観察事実から，タバコに放射線照射を適用して

1. 熟成の促進

2. 寄生昆虫のコントロール

3. 附着細菌のコントロール

4. 香契味の高品位化

に有用な効果を期待できる。観察はほ上んどが最終製品について行われたが，原料葉から最釉製 品に至るまでのそれそれの処理段階に適した工程での照射による観察が今後行なわれる必要があ ることを強調しておきたい。

なお本題に関連したもの上して「焦げた香味に放射線照射が有用であることが多い」かどかか の問題，「一般嗜好品に対する照射の有用の可能性」の問題，「アルカロイド類への照射の質的 あるいは量的奻果」の問題に対する今後の検討を提起しておきたい。

文献

1) BaIdw1n,R.R.et aI: U.S.Patent I3,149,977,1964

2) Tво.T.C.and Jeffrey,R.N.:Arch.B10chem.and B10phys., $\underline{43}$, $269(1953)$

3）伊沢正夫, 小橋友助：農化，曻，754（1955)

4) Hamer, D.and Woodhouse. D.L.:Brit.J.Cancer, 10,49 (1956)

5) Kовак, A.I. Swinehart, J.S. and Taher,D.: J.Natl.Cancer $I n=t .17,376(1956)$

6) Wynder,E.L.andWeiss,W.A.: Cancer, 10,255 (1957)

7) Wynder, E.L.: Brit.Med.J.,Feb.7,317 (1959)

8) We1ss,W.and W.A.Weies: Arah.Environmental Haclth, 9 , $500(1964)$

9) We188,W.:1b1d, 10,904(1965)

10) Wang, H. : Nat*re, 197, $946(1963)$

11）础田媇，加藤智雄，谷户惠子：日本衛生学雑誌，21，325（1966） 